\title{
Article \\ Innovative Recovery of Winemaking Waste for Effective Lead Removal from Wastewater
}

\author{
Gabriela Ungureanu ${ }^{1}$, Antoanela Patras ${ }^{1, * \mathbb{D}}$, Irina Gabriela Cara ${ }^{2}$, Rodica Sturza ${ }^{3}$ and \\ Aliona Ghendov-Mosanu ${ }^{3}$ (D)
}

1 Faculty of Horticulture, "Ion Ionescu de la Brad" Iasi University of Life Sciences, 3 Mihail Sadoveanu Alley, 700490 Iasi, Romania; ing.gabriela.ungureanu@gmail.com

2 Research Institute for Agriculture and Environment, "Ion Ionescu de la Brad" Iasi University of Life Sciences, 9 Mihail Sadoveanu Alley, 700789 Iasi, Romania; carairina@uaiasi.ro

3 Faculty of Food Technology, Technical University of Moldova, 9/9 Studentilor Str., MD-2045 Chisinau, Moldova; rodica.sturza@chim.utm.md (R.S.); aliona.mosanu@tpa.utm.md (A.G.-M.)

* Correspondence: apatras@uaiasi.ro

check for updates

Citation: Ungureanu, G.; Patras, A.; Cara, I.G.; Sturza, R.; GhendovMosanu, A. Innovative Recovery of Winemaking Waste for Effective Lead Removal from Wastewater. Agronomy 2022, 12, 604. https://doi.org/ 10.3390/agronomy12030604

Academic Editors: Vito Michele Paradiso, Ângela Fernandes and Marta Igual Ramo

Received: 13 February 2022 Accepted: 25 February 2022 Published: 28 February 2022

Publisher's Note: MDPI stays neutral with regard to jurisdictional claims in published maps and institutional affiliations.

Copyright: (C) 2022 by the authors. Licensee MDPI, Basel, Switzerland. This article is an open access article distributed under the terms and conditions of the Creative Commons Attribution (CC BY) license (https:// creativecommons.org/licenses/by/ $4.0 /)$.

\begin{abstract}
Every year, important quantities of winemaking waste create problems for wine producers. These problems arise from the difficulty of disposing of grape marc, which can pollute the environment and affect nearby agricultural crops. The present research proposes a new direction for the valorization of this agri-food waste in residual water depollution. Four biomaterials obtained from winemaking waste were tested for $\mathrm{Pb}$ removal: raw Merlot grape marc (MR), raw Sauvignon Blanc grape marc (SbR), Merlot grape marc biorefined (ME) and Sauvignon Blanc grape marc biorefined $(\mathrm{SbE})$. The effects of biosorbent mass and initial $\mathrm{Pb}$ concentration, adsorption kinetic, equilibrium isotherms and the matrix influence from a mine effluent were assessed. Very good perspectives for the practical application in lead uptake from wastewaters arise, with better results for biorefined grape marc compared to raw material. The lead removal percentage from an initial solution containing $20 \mathrm{mg} \mathrm{Pb} / \mathrm{L}$, at optimum pH (5.5 \pm 0.5$)$ was $71 \%-\mathrm{MR}, 78 \%-\mathrm{SbR}, 80 \%-\mathrm{ME}$, and $97 \%-\mathrm{SbE}$. A Langmuir model revealed a very good removal capacity for ME (40 mg/g) and SbE (64 mg/g). Thus, the grape marc, a polluting waste, can turn into a low-cost and easy-to-prepare sorbent for the bioremediation of contaminated water.
\end{abstract}

Keywords: grape marc; agri-food industrial wastes; water treatment; heavy metals; biomaterials; bioremediation

\section{Introduction}

For both soil and water, the agricultural industry together with food and beverage manufacturing are high-polluting industries, generating large quantities of wastes with a high organic load and easy microbiological contamination. The transport, treatment, and storage of these wastes inevitably lead to a price increase of the final product. The valorization of these agri-food industrial wastes represents a very good opportunity to develop new useful bioproducts in the frame of a circular bioeconomy and sustainable waste utilization. Possible directions of valorization are the production of biofuel, compost, or animal feed [1,2]. However, the waste biomass resulting from fruit and vegetable processing industry possesses large quantities of fibers and bioactive ingredients as polyphenols, vitamins, enzymes, oils, and carotenoids, which require reconsideration of the strategy of using this food waste. The phytochemicals present in this residual biomass can be valorized in nutritional supplements, natural food additives, and innovative functional foods through the extraction of natural antioxidants, antimicrobial substances, flavors, dyes, and texturizers [3]. However, these extractions lead to a series of completely depleted residues, which could be further valorized. Landfilling or incineration of these wastes only worsens the pollution problem, even if at first glance they may seem to be fast, low-priced solutions. 
In recent years, studies explored the possibility of using agri-food industrial wastes, which are easily available all over the world, as biosorbents with different applications. Adsorption represents a low-cost, highly efficient procedure, with possible metal recovery and adsorbent regeneration and minimum sludge production. Wastes from fruit and vegetable processing industries were investigated for removal of several harmful contaminants from wastewaters. Thus, attempts were made to solve pollution challenges by finding solutions that are as cheap and as environmentally friendly as possible.

Ample previous research investigated compounds which could be extracted from agri-food wastes [4-6]. Here, the extraction processes are described in detail, ample characterizations of the obtained extracts are presented, and possible practical applications of these compounds are indicated. The winemaking wastes can be valorized by the extraction of many bioactive compounds and their use in functional foods, playing the role of natural dyes (anthocyanins from red grapes), antioxidants (phenolic compounds), and antimicrobial agents which extend the shelf-life of the products (most of the phenolics), etc. In the present research, after the extraction of these valuable, water-soluble compounds (in order to valorize them by one of the mentioned methods), the remaining material is proposed to be used as adsorbent for $\mathrm{Pb}$ removal from polluted water. If this research will lead to good results in the $\mathrm{Pb}$ depollution of wastewater, then this waste (the grape marc) will have found its complete use and no part of it will be thrown away. Thus, the concept "zero waste" will be reached in this case and the wine industry will have an opportunity to become the source of two important products: wine and a new Pb removal material. The further development of this idea may bring three benefits: environmental (depollution); economical (financial profit from the commercialization of the new $\mathrm{Pb}$ removing material); and health (valorization of the extracted bioactive water-soluble compounds in food supplements, functional foods, or other health-promoting products).

Actually, the biomass precursor as feedstock for biosorbents production is diverse, beginning with fruits [7-9], vegetables $[10,11]$, or by-products resulting from numerous industrial agri-food processes $[12,13]$. Also, biosorbents have been used as such, or different types of pre-treatments have been applied [14] in order to increase their capacity to retain contaminants. Recent studies have gone even further and transformed these biosorbents into biochar [15] or activated carbon [16,17] by various methods, but these processes increase the price of the adsorbent, especially in the case of activated carbon.

The present research investigates the performance of an eco-friendly adsorbent derived from grape marc, in raw form or after the extraction of water-soluble compounds (biorefined), for the adsorptive removal of a heavy metal (lead) from contaminated effluents. Heavy metals are found in nature (soil, water, or wastewaters), coming from natural sources or human activities (mining, industry, agriculture). However, independently of their source, heavy metals have an extremely high level of toxicity to living organisms, especially if they: are in cationic form and associated with a carbon chain; are extremely easily absorbed by living organisms, and have extraordinary levels of bioaccumulation, causing serious health problems. In particular, lead is a tremendously toxic contaminant, resulting from the production of lead-acid batteries, paints, pigments, glass, chemicals, or from the pesticides industry and it has very serious implications for human health such as memory loss, headaches, gastrointestinal diseases, injuries of the central nervous system, and kidney complications [18]. The aim of the present study is (i) preparation of grape marc derived biosorbents; and (ii) batch mode experiments to test their $\mathrm{Pb}$ removal capacities (by finding the optimum $\mathrm{pH}$ conditions, the best liquid-solid ratio, and the influence of the initial adsorbent dosage, as well as the effect of initial pollutant concentration and the time required to reach equilibrium). The assays are conducted with synthetic effluents simulating lead contaminated wastewater but a real effluent is also tested. To the best of our knowledge, the grape marc is studied for the first time as heavy metal adsorbent for environmental bioremediation. 


\section{Materials and Methods}

\subsection{Chemicals}

A stock solution of $1000 \mathrm{mg} / \mathrm{L} \mathrm{Pb}^{2+}$ was prepared by the dissolution of $\mathrm{Pb}\left(\mathrm{NO}_{3}\right)_{2}$ (Merck, analytical grade) in distilled water. The lead solutions used in the subsequent biosorption tests were prepared by appropriate dilution of the stock solution. The $\mathrm{pH}$ was adjusted to the required values using $\mathrm{HNO}_{3}$ and $\mathrm{NaOH}$ aqueous solutions, prepared from $\mathrm{HNO}_{3} 65 \%$ (Chemicals) and $\mathrm{NaOH} 1 \mathrm{~N}$ standard solution (Chemicals). All the solutions were prepared in distilled water.

\subsection{Glassware Preparation}

All of the glassware and the plastic materials used in experimental tests were washed by soaking for $24 \mathrm{~h}$ in $\mathrm{HNO}_{3} 20 \%$ solution, rinsed with distilled water, and then dried.

\subsection{Biosorbent Preparation and Characterization}

The grape marc material is the winemaking waste resulted from Merlot and Sauvignon Blanc varieties, and it was provided by the Research and Development Station for Viticulture and Winemaking, Iasi, Romania. The sorbents MR (raw Merlot grape marc) and SbR (raw Sauvignon Blanc grape marc) were represented by the mentioned grape marc, convective dried at $45^{\circ} \mathrm{C}$, up to $9 \%$ moisture. A constant-temperature drying oven Biobase, BOV-T30C (Jinan, China) was used. The sorbents ME (Merlot grape marc after biorefining) and $\mathrm{SbE}$ (Sauvignon Blanc grape marc after biorefining) were obtained from MR and SbR, respectively, after the removal of the water-soluble compounds, following a four-step procedure:

(1) A quantity of $4 \mathrm{~g}$ of dry marc with $9 \%$ moisture were exactly weighted with a 4-decimal analytical balance and introduced in an Erlenmeyer flask with $500 \mathrm{~mL}$ distilled water. The extraction was performed for $40 \mathrm{~min}$, at room temperature, using an ultrasonic bath (MRC, model AC-120H, Essex, UK), ultrasonic frequency $40 \mathrm{kHz}$, followed by filtration.

(2) The entire solid residue resulted after the filtration was carefully collected and introduced in an Erlenmeyer flask and $500 \mathrm{~mL}$ distilled water was added. The previous extraction procedure was repeated for $40 \mathrm{~min}$, and it was again followed by filtration.

(3) The solid residue resulted after the second filtration was collected and extracted again in the presence of $500 \mathrm{~mL}$ distilled water, but only for $20 \mathrm{~min}$, followed by filtration.

(4) The solid residue resulting from the previous step was collected, $500 \mathrm{~mL}$ distilled water was added and the 20 min extraction was repeated, followed by filtration. The solid material collected from the filter paper after the fourth extraction was convective dried at $45{ }^{\circ} \mathrm{C}$, up to $9 \%$ moisture (similar to the raw material) and represented the $\mathrm{ME}$ and $\mathrm{SbE}$ sorbents, respectively.

The ratio between dried marc and the total volume of distilled water used during the four steps was 2:1000 $(\mathrm{g} / \mathrm{mL})$. During the four extractions, the average temperature of the water of the ultrasonic bath was $27 \pm 2{ }^{\circ} \mathrm{C}$.

The four biosorbents obtained from grape marc were characterized by the FTIR spectroscopy (Fourier transform infrared spectroscopy) for the qualitative evaluation of functional groups on the material surface. A Jasco 4000 Series (Japan) FT-IR spectrometer was used to obtain the infrared spectra recorded in a range of 400 to $4000 \mathrm{~cm}^{-1}$. Without being mixed with other substances, the samples of dried biosorbents were ground and directly applied on a diamond reflection attenuated total reflectance (ATR) device. Careful cleaning of the crystal was performed prior to each analysis with ultrapure water and isopropanol.

\subsection{Adsorption Studies}

\subsubsection{Heavy Metal Quantification}

Atomic adsorption spectrometry, AAS (spectrophotometer ContrAA 700, Analytik Jena, Jena, Germany) was used to determine the initial and the remaining lead concentration 
in the supernatant after contact time. Analyses were completed using air/acetylene ( $99.95 \%$ purity) flame with triplicate readings, $217 \mathrm{~nm}$ wavelength, automatically through software background correction. Calibration curves were performed before each analysis in a range of $0-20 \mathrm{mg} / \mathrm{L}$ or $0-100 \mathrm{mg} / \mathrm{L}$ (depending on the concentration of the samples to be analyzed), with a determination coefficient of $R^{2}>0.995$. The detection limit was $0.04 \mathrm{mg} / \mathrm{L}$ and the quantification limit was $0.15 \mathrm{mg} / \mathrm{L}$. Before AAS analysis, the samples were filtered using cellulose acetate membrane filters ( $45 \mu \mathrm{m}$ porosity). The same technique was applied to determine the metal content of the Rosia Montana mining effluent.

\subsubsection{Batch-Mode Biosorption Studies}

Different tests were performed in order to establish the most appropriate conditions for $\mathrm{Pb}$ removal using grape-marc derived materials. All adsorption tests were realized in $100 \mathrm{~mL}$ Erlenmeyer flasks containing $25 \mathrm{~mL}$ lead solution and the grape marc sorbent (4-decimals weighed). The assays were conducted under constant orbital rotation of $120 \mathrm{rpm}$ at $22 \pm 1{ }^{\circ} \mathrm{C}$. The $\mathrm{pH}$ was maintained constant with an acceptable variation of \pm 0.5 . After each adsorption test, the lead remaining in the solution was measured (AAS) and the adsorption capacity of the sorbent was evaluated.

The adsorption capacity at equilibrium $\left(q_{e}, \mathrm{mg} / \mathrm{g}\right)$ represented the Pb quantity $(\mathrm{mg})$ retained by the grape marc, per mass unit of the adsorbent $(\mathrm{g})$ at equilibrium, and it was calculated by the Equation (1):

$$
q_{e}=\frac{C_{i n}-C_{f}}{\mathrm{~m}} V
$$

where $C_{\text {in }}$ is the initial $\mathrm{Pb}$ concentration in the liquid phase $(\mathrm{mg} / \mathrm{L}), C_{f}$ is the concentration after adsorption $(\mathrm{mg} / \mathrm{L}), \mathrm{m}$ is the sorbent mass $(\mathrm{g})$, and $V$ is the solution volume $(\mathrm{L})$.

The removal efficiency (\% removal) was calculated by Equation (2):

$$
\% \text { removal }=\frac{C_{i n}-C_{f}}{C_{i n}} 100
$$

$\mathrm{pH}$ Test

For the determination of the optimum $\mathrm{pH}$ for $\mathrm{Pb}$ removal by grape marc, three $\mathrm{pH}$ values $\left(2,3.5\right.$, and 5.5) were tested. The assay conditions were: $6 \mathrm{~h}$ contact time, $20 \mathrm{mg} / \mathrm{L} \mathrm{Pb}^{2+}$ initial concentration, and $1 \mathrm{~g} / \mathrm{L}$ adsorbent amount. The $20 \mathrm{mg} / \mathrm{L} \mathrm{Pb}^{2+}$ concentration was chosen due to the fact that this value is close to the $\mathrm{Pb}$ concentration in the wastewater released by lead battery manufacturing or recycling industries [19]. During the experiment, the $\mathrm{pH}$ was measured and adjusted with $\mathrm{HNO}_{3}$ or $\mathrm{NaOH}$ solutions (if necessary) so that the variation did not exceed \pm 0.5 units compared to the defined value.

\section{Adsorbent Concentration Assay}

After defining the ideal $\mathrm{pH}$ condition, the assays continued with the determination of the optimal adsorbent dosage. The tests were performed similarly ( $6 \mathrm{~h}$ of orbital shaking at $120 \mathrm{rpm}$ in Erlenmeyer flasks containing $25 \mathrm{~mL}$ of $20 \mathrm{mg} / \mathrm{L}$ lead solution at pH $5.5 \pm 0.5$ ). The tested concentrations were: $0.25,0.5,1,2,5$, and $10 \mathrm{~g} / \mathrm{L}$ of synthetic contaminated water.

\section{Biosorption Kinetics}

Kinetics evaluates how fast the biosorption process occurs. Thus, the effect of different contact times, between 5 to $480 \mathrm{~min}$, on lead adsorption was evaluated. For each reaction time previously established, an Erlenmeyer flask with $25 \mathrm{~mL}$ of $20 \mathrm{mg} / \mathrm{L}$ lead solution and $0.5 \mathrm{~g} / \mathrm{L}$ adsorbent was stirred. The lead concentration in liquid phase was determined and pseudo-first order and pseudo-second order models were fitted to experimental data. 
Biosorption Equilibrium Isotherms

Equilibrium isotherms for $\mathrm{Pb}^{2+}$ uptake by $\mathrm{ME}$ and $\mathrm{SbE}$ were performed at $\mathrm{pH} 5.5 \pm 0.5$, using $0.5 \mathrm{~g} / \mathrm{L}$ adsorbent. Erlenmeyer flasks with $25 \mathrm{~mL} \mathrm{~Pb}^{2+}$ solutions with initial concentrations 7.5, 25, 50, 70, 85, and $100 \mathrm{mg} / \mathrm{L}$ were stirred at $120 \mathrm{rpm}$ for $6 \mathrm{~h}$. Following the analysis of the results obtained in the kinetics study, the reaction time of $6 \mathrm{~h}$ was used to guarantee the achievement of equilibrium for each concentration, given that this time far exceeded the time required to reach equilibrium.

\subsubsection{Mine Drainage Wastewater Assay}

The lead uptake capacity of the studied biosorbents was also tested in the presence of other ions, using a real effluent with a complex matrix. The real wastewater sample was collected in Rosia Montana, a gold and silver mine that is located in TransylvaniaRomania where mining activity took place for over two thousand years. Presently, the mine is disabled. The sampling point was in the mine proximity and the drainage water presented a strong reddish color. A physicochemical characterization of the mining-drainage water was completed. The experimental conditions applied for this aqueous matrix were identical to those used for the synthetic lead solutions.

\subsection{Statistical Analysis}

Mathematical modeling of the experimental data obtained was performed by nonlinear regression adjustments with CurveExpert software. The global uncertainty of each result represented by the error bars was considered the maximum error involved in the calculation of the adsorbed amount, q.

\section{Results and Discussion}

\subsection{Characterization of the Sorbents by FTIR Analysis}

For the evaluation of the possible binding sites and adsorption mechanism, it is important to identify the functional groups present on the surface of the biosorbents. The spectra of the four sorbents (Figures 1-4) indicates the existence of functional groups which are typically found in grape marc $(-\mathrm{OH},-\mathrm{CO},-\mathrm{CH}$, and $\mathrm{C}-\mathrm{O}-\mathrm{H})$ due to the presence of lignin, cellulose and hemicellulose, and phenolic compounds.

The bands between $\approx 3311$ to $3009 \mathrm{~cm}^{-1}$ correspond to $\mathrm{OH}$-(phenols, and cellulose alcohols) $[20,21]$. The peaks at $\approx 2900-2850 \mathrm{~cm}^{-1}$ match $-\mathrm{CH}$ asymmetric stretching of alkane [8], methyl-methylene [16], or aliphatic groups [22]. The distinctive peaks at $\approx 1740-1745 \mathrm{~cm}^{-1}$ are due to carboxylic groups indicating the presence of phenolic acids [20] and the peaks at $\approx 1605 \mathrm{~cm}^{-1}$ (-CO) are typical spectra for polysaccharides, and for cellulose and hemicellulose [23]. The bands around 1420-1200 $\mathrm{cm}^{-1}$ correspond to flavonoids (possible based tannins) and the peaks at $\approx 1030 \mathrm{~cm}^{-1}$ are characteristic of the presence of phenolic compounds (C-O-H) [20]. All peaks below $990 \mathrm{~cm}^{-1}$ are representative of the presence of aromatic structures [20] or hydrocarbon $(-\mathrm{C}-\mathrm{H})$ with great affinity for the capture of heavy metal ions [16]. The spectra attained for each type of grape-marc are quite alike. Although water-soluble compounds were extracted by sequential extraction processes, as can be concluded from the FTIR results, the extraction is not complete because the representative peaks continue to exist in $\mathrm{ME}$ and $\mathrm{SbE}$, but with a lower absorbance.

The adsorption mechanisms are various, and they may occasionally occur simultaneously. Chemisorption is one of these mechanisms, and it can be achieved by ion exchange, chelation, complexation, or coordination [24]. The presence of carboxyl, hydroxyl, and ester groups evidenced by FTIR analysis could explain the biosorption mechanism of lead ions onto the grape marc by attraction/chelation between $\left(\mathrm{Pb}^{2+}\right)$ positive charged and $\left(-\mathrm{COO}^{-}\right) /\left(\mathrm{OH}^{-}\right)$negative charged, since carboxylic and hydroxyl groups are deprotonated at $\mathrm{pH}>4$. Lead is known to have a tendency to form coordinate (dative) bonds $[25,26]$. 


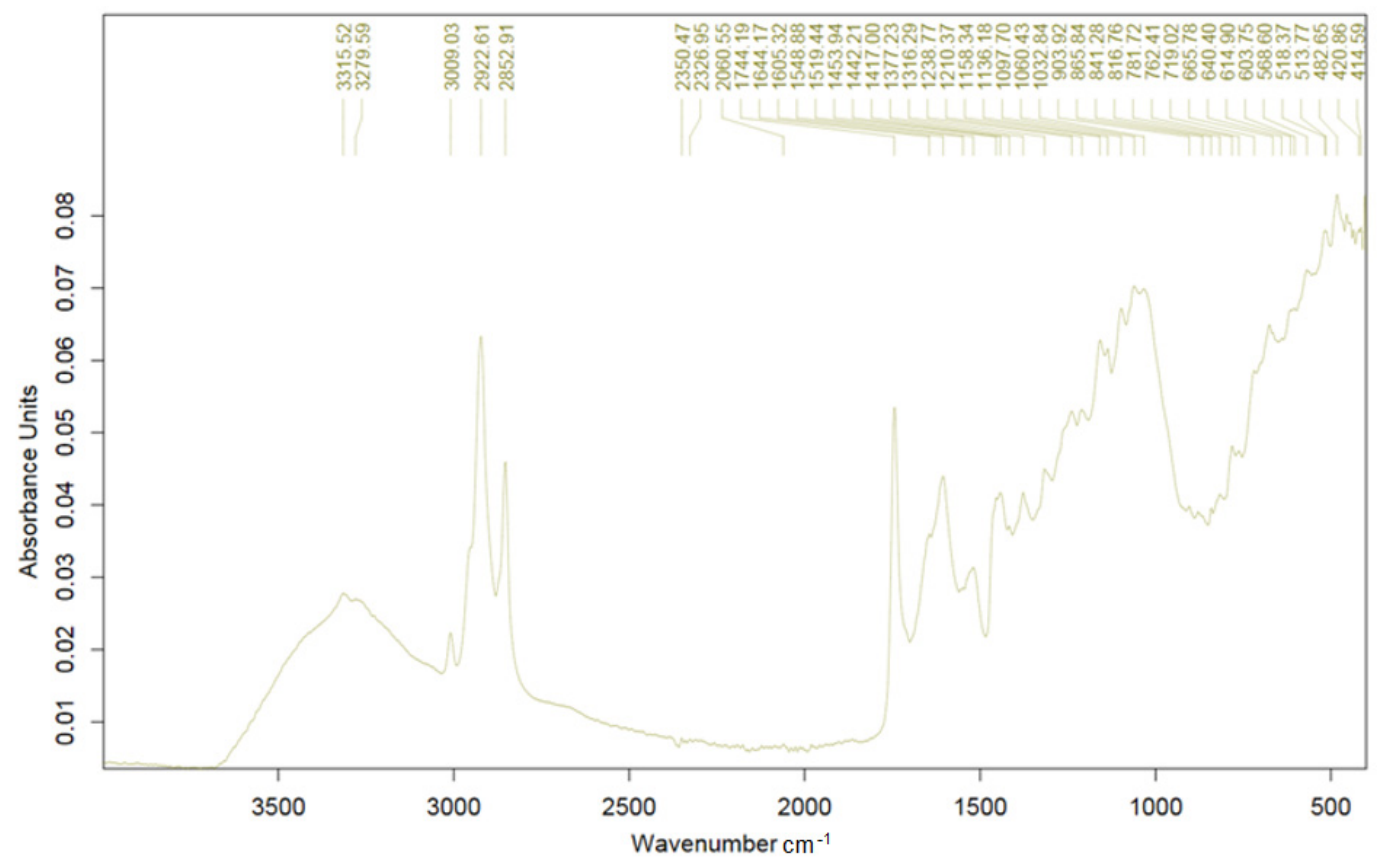

Figure 1. FTIR spectra of raw Merlot grape marc.

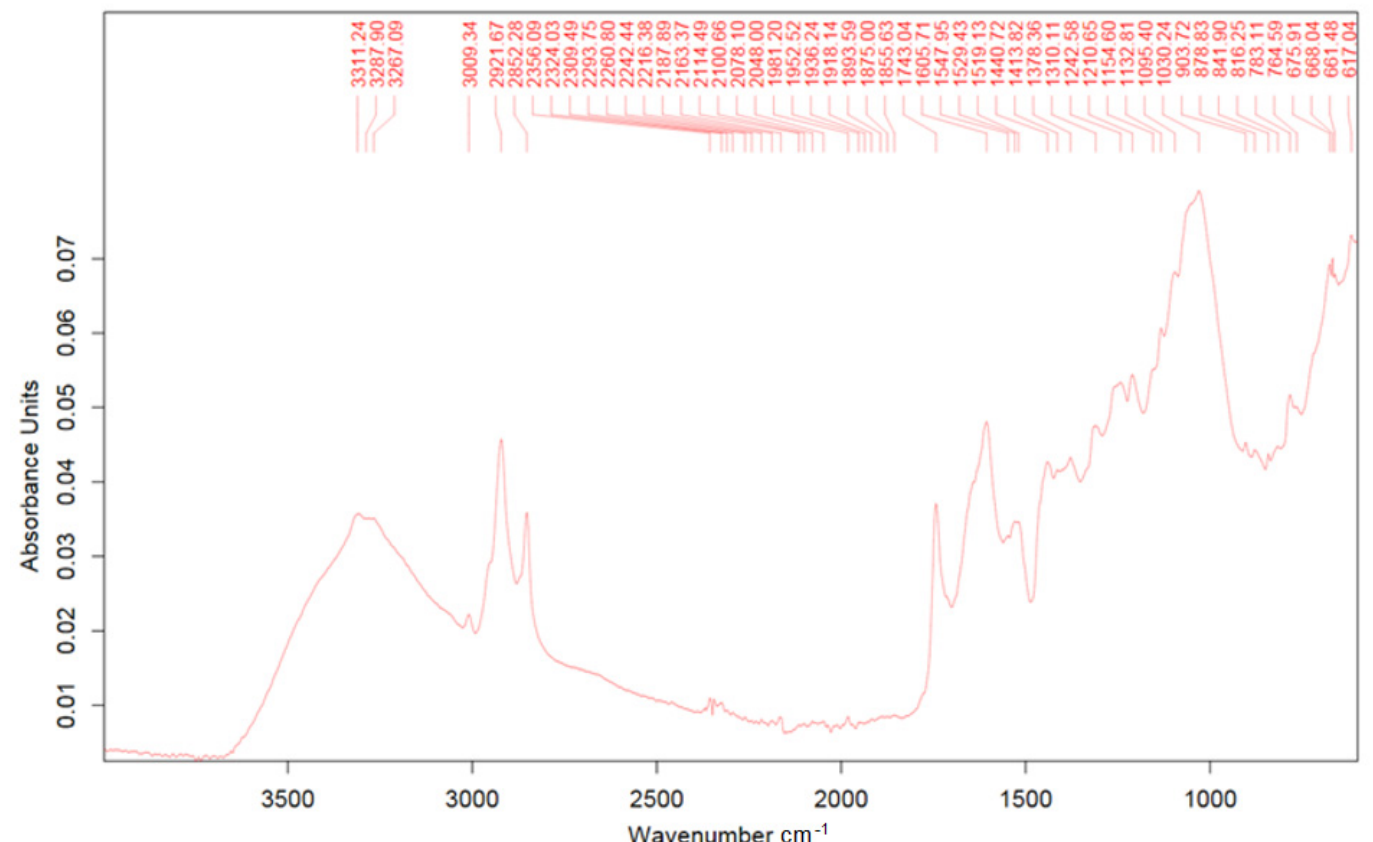

Figure 2. FTIR spectra of raw Sauvignon Blanc grape marc.

\subsection{Effect of $\mathrm{pH}$ on the $\mathrm{Pb}^{2+}$ Removal}

The $\mathrm{pH}$ level is an important factor to evaluate the retention capacity of an adsorbent on this parameter depending the availability of functional groups of the solid surface to establish chemical bonds and to fix the pollutant ions. Preliminary tests were performed with $\mathrm{MR}, \mathrm{ME}, \mathrm{SbR}$, and $\mathrm{SbE}$ for $\mathrm{pH} 2,3.5$, and 5.5. All tested biosorbents were shown to be effective for $\mathrm{Pb}^{2+}$ removal, but they were strongly affected by the $\mathrm{pH}$ (Figure 5). 


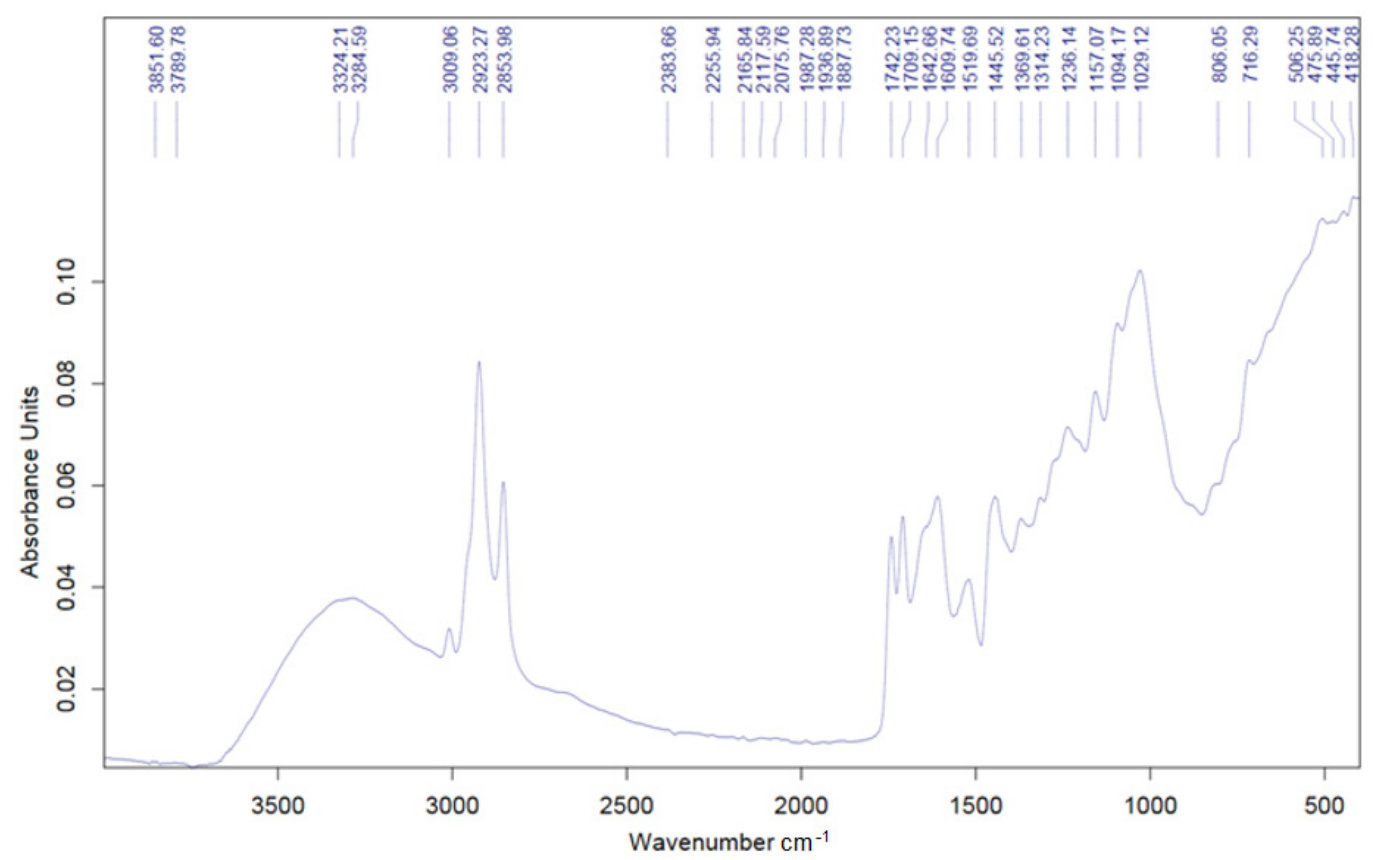

Figure 3. FTIR spectra of Merlot grape marc after biorefining.

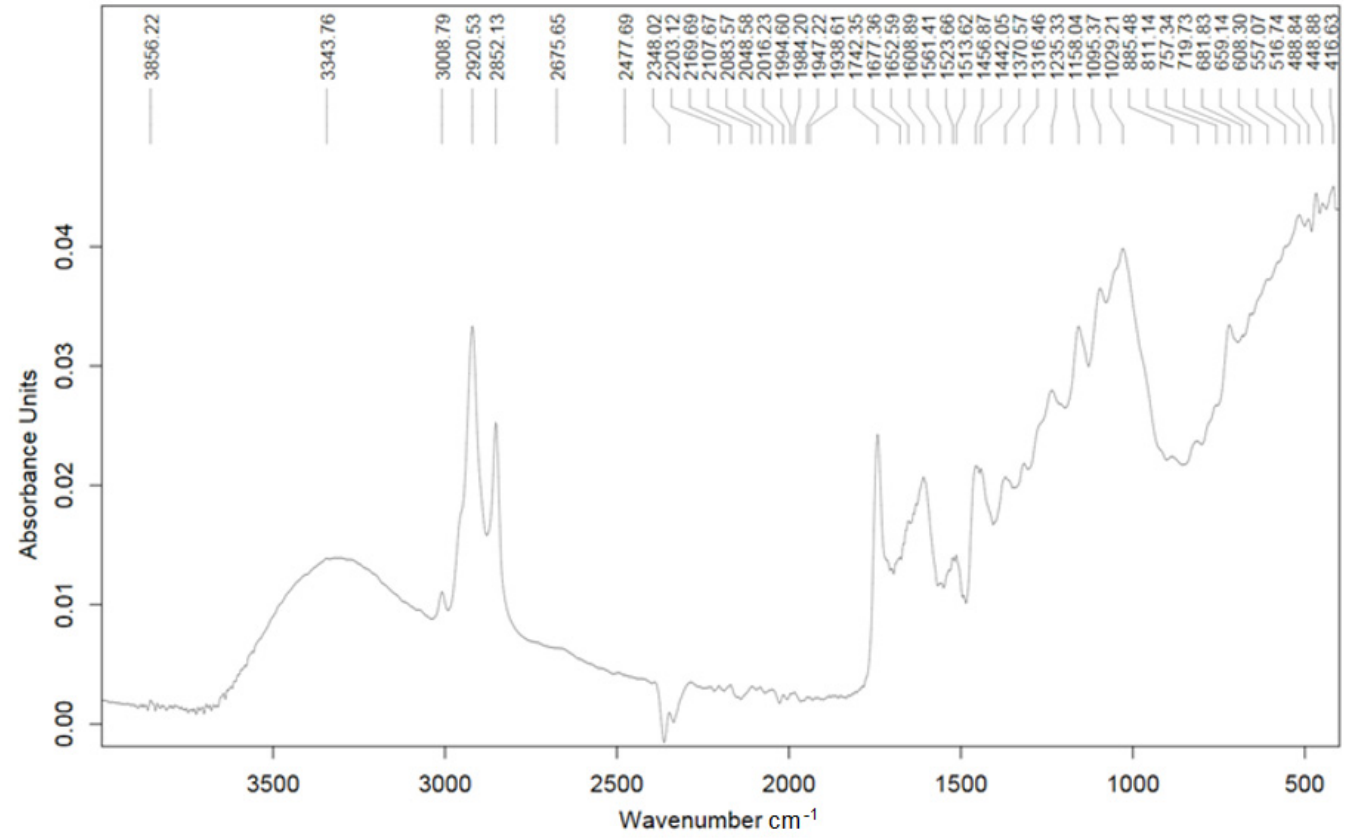

Figure 4. FTIR spectra of Sauvignon Blanc grape marc after biorefining.

The $\mathrm{pH}$ level was regularly verified during the contact time, and it was adjusted to the required value (maximum variation permitted was \pm 0.5 units) by small additions of base or acid solutions. As $\mathrm{Pb}$ precipitation easily occurs for $\mathrm{pH}$ levels higher than 6.0 (especially for concentrated solutions) and since real effluents, contaminated with lead, present an acidic $\mathrm{pH}$, either mining wastewater [27] or industrial polluted waters from lead battery manufacturing or recycling industries $[19,28]$, the $\mathrm{pH}$ effect was studied only in the interval between 2 and 5.5. The results represented in Figure 5 indicate that the $\mathrm{pH}$ augmentation leads to an increase in $\mathrm{Pb}$ uptake from extremely low values for $\mathrm{pH} 2$, up to $97 \%$ for $\mathrm{pH} 5.5$ $(\mathrm{SbE})$. This can be explained by the fact that at extremely low $\mathrm{pH}$ values, lead is present as cation $\left(\mathrm{Pb}^{2+}\right)$ and the protons $\left(\mathrm{H}^{+}\right)$compete with lead ions to occupy the available positions on the biosorbent surface, greatly limiting the adsorption of lead. Additionally, Figure 5 
shows that depleted forms of grape marc, for both Merlot (ME) and for Sauvignon Blanc $(\mathrm{SbE})$, retain better $\mathrm{Pb}^{2+}$ than the raw materials.

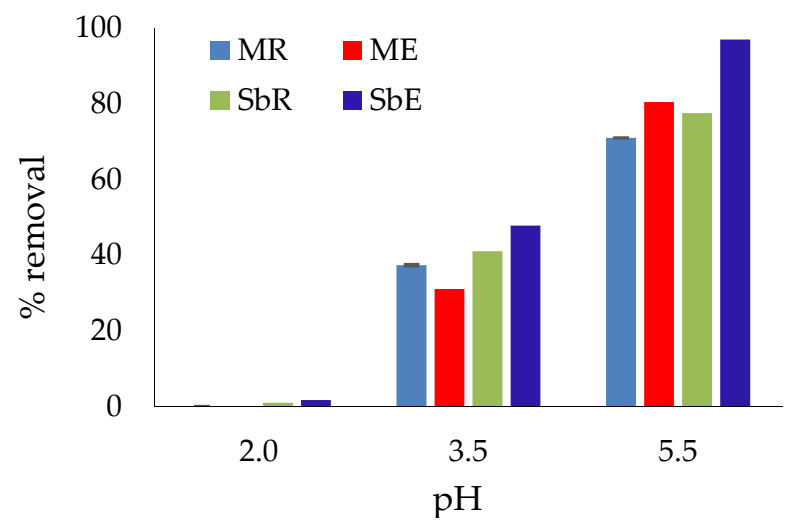

Figure 5. Removal efficiency of $\mathrm{Pb}^{2+}$ by $\mathrm{MR}, \mathrm{ME}, \mathrm{SbR}$, and $\mathrm{SbE}$ at different $\mathrm{pH}, 20 \mathrm{mg} / \mathrm{L} \mathrm{Pb}^{2+}$ solution, $1 \mathrm{~g} / \mathrm{L}$ adsorbent concentration, $22^{\circ} \mathrm{C}$.

The results revealed by the $\mathrm{pH}$ tests were used to select the better parameters for the following part of the study. Consequently, the $\mathrm{pH} 5.5$ and the biosorbents which proved to have the best removal potential at this $\mathrm{pH}$ (ME and $\mathrm{SbE}$ - which are the biorefined forms of both grape marc varieties) were selected.

\subsection{Effect of Adsorbent Concentration on the $\mathrm{Pb}^{2+}$ Removal}

The effect of adsorbent concentration was studied for $0.25,0.5,1,2,5$ and $10 \mathrm{~g}$ refined grape marc/L of contaminated water, respectively. The obtained results were expressed as a percentage of removal efficiency and adsorption capacity (Figure 6).

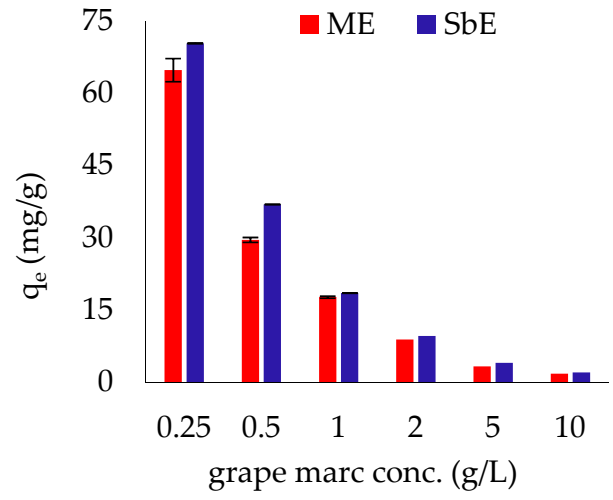

(a)

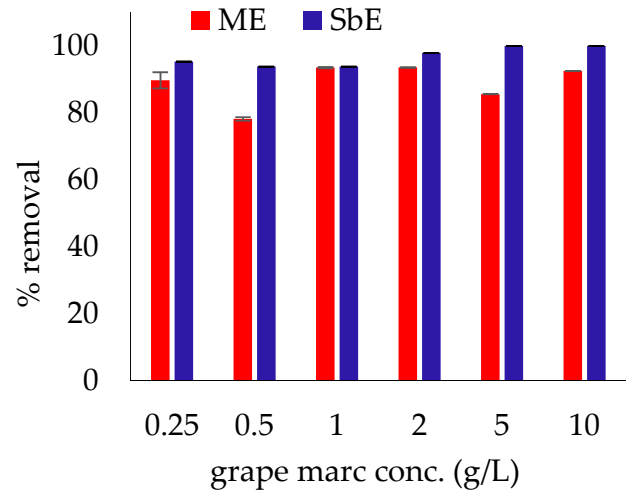

(b)

Figure 6. Adsorption capacity (a) and removal efficiency (b) by ME and SbE at different adsorbent concentrations, $20 \mathrm{mg} / \mathrm{L}$ of $\mathrm{Pb}^{2+}$ solution, $\mathrm{pH} 5.5 \pm 0.5,22{ }^{\circ} \mathrm{C}$.

Concerning the removal efficiency: with the exception of ME- $-0.5 \mathrm{~g} / \mathrm{L}$, all results indicate a lead uptake percentage between 80 and $100 \%$, which corresponds to adsorption capacities from $64.7 \pm 2.4 \mathrm{mg} / \mathrm{g}$ for solid/liquid ratio of $0.25 \mathrm{~g} / \mathrm{L}$ to $1.75 \pm 0.01 \mathrm{mg} / \mathrm{g}$ for $10 \mathrm{~g} / \mathrm{L}$ for $\mathrm{ME}$ and $70.34 \pm 3.06 \mathrm{mg} / \mathrm{g}$ for solid/liquid ratio of $0.25 \mathrm{~g} / \mathrm{L}$ to $1.989 \pm 0.004 \mathrm{mg} / \mathrm{g}$ for $10 \mathrm{~g} / \mathrm{L}$ for $\mathrm{SbE}$, respectively. Although the highest value of the adsorption capacity is attained for a biosorbent amount of $0.25 \mathrm{~g} / \mathrm{L}$ (equivalent to $0.0065 \mathrm{mg}$ biosorbent in $25 \mathrm{~mL}$ of lead solution), the use of this biosorbent amount for the following experiments could generate errors. For this reason, a dosage of $0.50 \mathrm{~g} / \mathrm{L}$ biosorbent was selected to be used in further assays. 


\subsection{Adsorption Kinetic Studies}

Biosorption kinetics of $\mathrm{Pb}^{2+}$ on $\mathrm{ME}$ and $\mathrm{SbE}$ was studied at $\mathrm{pH} 5.5$ (optimum $\mathrm{pH}$ condition) and the samples were collected at pre-established contact times between 5 to $480 \mathrm{~min}$. Figure 7 depicts the effect of contact time (t) on the normalized concentration $\left(\mathrm{C} / C_{\text {in }}\right)$ decay of lead in the liquid phase.

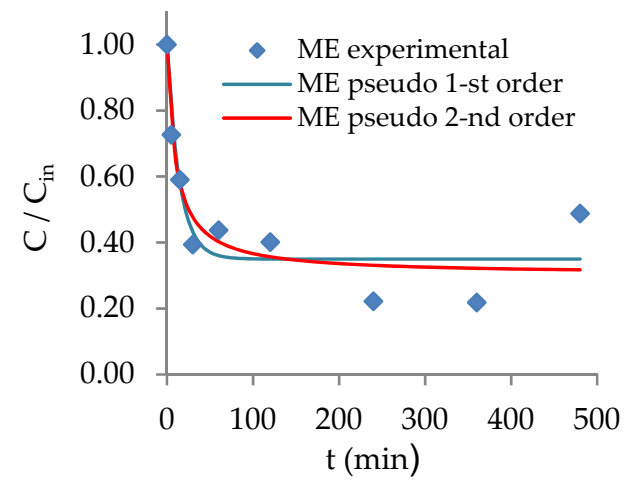

(a)

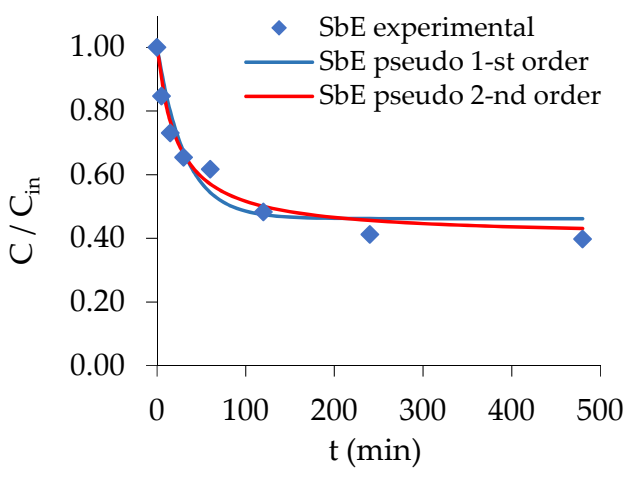

(b)

Figure 7. Effect of contact time on $\mathrm{Pb}^{2+}$ biosorption on (a) $\mathrm{ME}$ and (b) $\mathrm{SbE}, 20 \mathrm{mg} / \mathrm{L} \mathrm{Pb}^{2+}$ solution, $\mathrm{pH} 5.5 \pm 0.5,0.50 \mathrm{~g} / \mathrm{L}$ biosorbent, $22{ }^{\circ} \mathrm{C}$ : experimental data and modelling (— Pseudo-first order model; - Pseudo-second order).

Lead adsorption is a fast process, as can be seen in Figure 7. In the first $30 \mathrm{~min}, \mathrm{ME}$ $60 \%$ of the maximum $\mathrm{Pb}^{2+}$ adsorbed amount was already achieved and $35 \%$ for $\mathrm{SbE}$. For both biosorbents, the time necessary to reach the equilibrium is slightly over $2 \mathrm{~h}$. Similar results have been reported in the literature for other biosorbents applied to remove lead from aqueous solutions $[29,30]$. This expeditious equilibrium time represents an advantage from an operational point of view in case of its practical application. The experimental data were mathematically adjusted by Lagergren (1898) pseudo-first-order (Equation (3)) and pseudo-second order models (Equation (4)) [31].

$$
\begin{gathered}
q=q_{e}\left(1-e^{-k_{1} t}\right) \\
q=q_{e} \frac{\mathrm{k}_{2} \mathrm{q}_{\mathrm{e}}^{2} \mathrm{t}}{1+k_{2} q_{e} t}
\end{gathered}
$$

where $q(\mathrm{mg} / \mathrm{g})$ is the biosorbed amount for a contact time $\mathrm{t}(\mathrm{min}) ; q_{e}(\mathrm{mg} / \mathrm{g})$ is the biosorbed amount at equilibrium; and $k_{1}\left(\mathrm{~min}^{-1}\right)$ and $\mathrm{k}_{2}\left(\mathrm{~g} \mathrm{mg}^{-1} \mathrm{~min}^{-1}\right)$ are the kinetic constants of the models. Both models were fitted to the experimental data by non-linear regression adjustments and the results are presented in Table 1.

\begin{tabular}{|c|c|c|c|c|c|c|c|c|}
\hline & \multicolumn{4}{|c|}{ Pseudo-1st Order Model } & \multicolumn{4}{|c|}{ Pseudo-2nd Order Model } \\
\hline & $k_{1}\left(\min ^{-1}\right)$ & $q_{e q}(\mathrm{mg} / \mathrm{g})$ & $\mathbf{R}^{2}$ & SE & $\begin{array}{c}k_{2} 10^{3}\left(\mathrm{~g} \mathrm{mg}^{-1}\right. \\
\left.\min ^{-1}\right)\end{array}$ & $q_{e q}(\mathrm{mg} / \mathrm{g})$ & $\mathbf{R}^{2}$ & SE \\
\hline ME & $0.07 \pm 0.02$ & $24.7 \pm 1.8$ & 0.70 & 3.89 & $0.004 \pm 0.002$ & $26.5 \pm 1.9$ & 0.78 & 3.38 \\
\hline $\mathrm{SbE}$ & $0.031 \pm 0.008$ & $20.4 \pm 1.4$ & 0.88 & 2.34 & $0.0019 \pm 0.0004$ & $22.69 \pm 1.08$ & 0.96 & 1.32 \\
\hline
\end{tabular}

Table 1. Parameters obtained from kinetic model fittings (value \pm standard error of the coefficient).

A pseudo-second order model better describes the results with a higher determination coefficient $\left(\mathrm{R}^{2}\right)$, lower standard error (SE) and with predicted values for the adsorbed amounts at an equilibrium $\left(q_{e}\right)$ closer to that of the experimental. 


\subsection{Equilibrium Studies}

It is important to know the maximum retention capacity of a biosorbent and the affinity of the solid to the adsorbate. This information is provided by equilibrium isotherms (Figure 8).

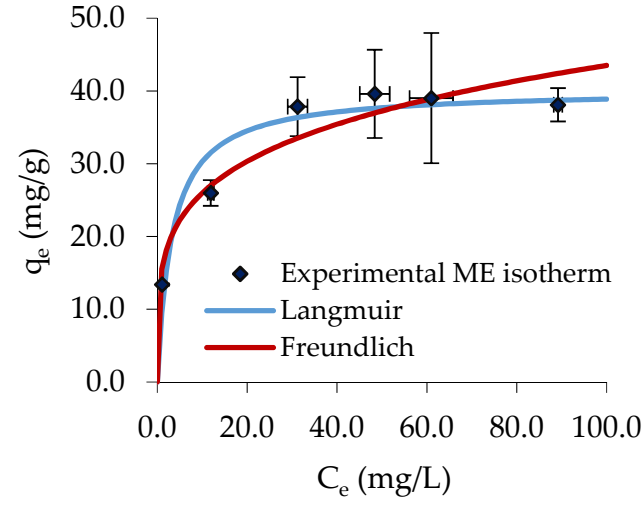

(a)

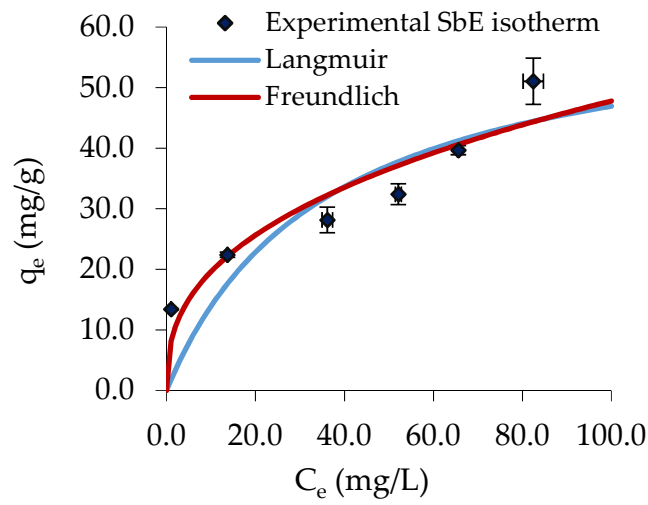

(b)

Figure 8. Equilibrium isotherms for $\mathrm{Pb}^{2+}$ biosorption on (a) $\mathrm{ME}$ and (b) $\mathrm{SbE}, \mathrm{pH} 5.5 \pm 0.5,0.50 \mathrm{~g} / \mathrm{L}$ biosorbent, $6 \mathrm{~h}$ contact time, $22{ }^{\circ} \mathrm{C}$ : experimental data and modelling (— Freundlich; — Langmuir).

As can be seen, the two isotherms present a high slope for low adsorbate concentrations. This means that both $\mathrm{ME}$ and $\mathrm{SbE}$ have a great affinity for $\mathrm{Pb}^{2+}$, and they are able to remove considerable amounts of adsorbate even from very low $\mathrm{Pb}$ levels. A grape marc concentration of $0.5 \mathrm{~g} / \mathrm{L}$ was able to remove $86 \%$ of lead from an initial low concentration of $7.5 \mathrm{mg} / \mathrm{L} \mathrm{Pb}^{2+}$ for both ME and SbE biosorbents. The well-known Langmuir (1918) and Freundlich (1906) equilibrium models were adjusted to the experimental data by non-linear regression. According to the Langmuir model, the surface-active sites are homogeneously dispersed on the surface of the adsorbent and adsorption is restricted to a monolayer coverage. The Freundlich isotherm is entirely empirical, and it is applicable to adsorption processes that occur on heterogonous surfaces. A major disadvantage of the Freundlich equation is that it does not predict an adsorption maximum. The Langmuir model is expressed by Equation (5)

$$
q_{e}=\frac{K_{L} Q_{\max } C_{e}}{1+K_{L} C_{e}}
$$

where $Q_{\max }$ signifies the maximum biosorption capacity, $C_{e}$ is lead concentration on equilibrium, and $K_{L}$ the Langmuir constant.

The Freundlich model is expressed by Equation (6)

$$
q_{e}=K_{F} C_{e}^{1 / n_{F}}
$$

where $K_{F}$ is a constant for the adsorbate-adsorbent system, correlated to the adsorption capacity; and, $n_{F}$ is a constant that shows the intensity of adsorption $\left(n_{F}>1\right.$, favorable isotherm; $n_{F} \leq 1$, unfavorable isotherm).

Table 2 describes the determined parameters for both models applied to experimental data. For an appropriate evaluation of fitting quality, regression standard error (SE) and determination coefficient $\left(R^{2}\right)$ are also presented, as statistic parameters.

For ME, both mathematical models describe experimental data with equivalent quality. For $\mathrm{SbE}$ biosorbent, the Freundlich model better fits the experimental values with lower standard errors and higher determination coefficients. Also, the values obtained for $n_{F}$ are above 1 , which indicates favorable isotherms. The Langmuir model indicates maximum adsorption capacities of $40 \mathrm{mg} / \mathrm{g}$ for ME and $64 \mathrm{mg} / \mathrm{g}$ for SbE, respectively. 
Table 2. Parameters (value \pm standard error of the coefficient) for Langmuir and Freundlich equilibrium models for the biosorption of $\mathrm{Pb}^{2+}$ by ME and $\mathrm{SbE}\left(\mathrm{pH} 5.5 \pm 0.5,0.50 \mathrm{~g} / \mathrm{L}\right.$ of biosorbent and $\left.22{ }^{\circ} \mathrm{C}\right)$.

\begin{tabular}{ccccccccc}
\hline & \multicolumn{3}{c}{ Langmuir Model } & \multicolumn{3}{c}{ Freundlich Model } \\
\cline { 2 - 9 } & $\boldsymbol{Q}_{\max }(\mathbf{m g} / \mathbf{g})$ & $\boldsymbol{K}_{\boldsymbol{L}}(\mathbf{L} / \mathbf{m g})$ & $\mathbf{R}^{\mathbf{2}}$ & $\mathbf{S E}$ & $\boldsymbol{n}_{\boldsymbol{F}}$ & $\boldsymbol{K}_{\boldsymbol{F}}\left(\mathbf{m g} / \mathbf{g}(\mathbf{m g} / \mathbf{L})^{-\mathbf{1} / \boldsymbol{n F})}\right.$ & $\mathbf{R}^{\mathbf{2}}$ & $\mathbf{S E}$ \\
\hline $\mathrm{ME}$ & $40.1 \pm 2.4$ & $0.3 \pm 0.1$ & 0.91 & 3.6 & $4.5 \pm 0.9$ & $15.5 \pm 2.5$ & 0.93 & 3.5 \\
\hline $\mathrm{SbE}$ & $63.75 \pm 25.02$ & $0.03 \pm 0.03$ & 0.71 & 7.9 & $2.6 \pm 0.7$ & $8.1 \pm 3.4$ & 0.87 & 5.3 \\
\hline
\end{tabular}

Some previous research studied $\mathrm{Pb}^{2+}$ retention using other agri-food industrial wastes and a comparison between our results and bibliographic data is presented in Table 3 .

Table 3. Lead adsorption capacities for several types of various agri-food industrial wastes.

\begin{tabular}{|c|c|c|c|c|c|c|}
\hline Biosorbent & Additional Treatments & $\begin{array}{c}\text { Initial } \mathrm{Pb} \\
\text { Concentration, } \mathrm{mg} / \mathrm{L}\end{array}$ & $\begin{array}{c}\text { Adsorbent } \\
\text { Amount, g/L }\end{array}$ & $\mathrm{pH}$ & $\begin{array}{c}\text { Adsorption } \\
\text { Capacity mg/g }\end{array}$ & References \\
\hline Merlot grape marc & Biorefinery & 20 & 0.5 & 5.5 & 40.1 & Present study \\
\hline $\begin{array}{c}\text { Sauvignon Blanc } \\
\text { grape marc }\end{array}$ & Biorefinery & 20 & 0.5 & 5.5 & 63.8 & Present study \\
\hline Peanut husk & Washed with $\mathrm{HCl}$ and $\mathrm{NaOH}$ & 20 & 5 & 6 & 27.03 & {$[32]$} \\
\hline Milled olive stones & Unmodified & 1 & 4 & 6 & 0.581 & {$[33]$} \\
\hline $\begin{array}{c}\text { Raw sugarcane } \\
\text { bagasse }\end{array}$ & $\begin{array}{l}\text { Pre-treated with } \mathrm{NaOH}, \\
\text { followed by epoxidation, } \\
\text { amination and sulfonation }\end{array}$ & 500 & 1.25 & 5 & 558.9 & {$[34]$} \\
\hline Oil tea Shell & Unmodified & 5 & 2 & 5 & 22.4 & [35] \\
\hline Hamimelon peels & $\mathrm{NaOH}$ treatment & 100 & - & 7 & 7.89 & {$[36]$} \\
\hline Cabbage Leaves & Unmodified & 50 & 10 & 6 & 6.31 & [37] \\
\hline
\end{tabular}

Table 3 confirms that another agri-food industrial waste with a very high lead adsorption capacity (raw sugarcane bagasse) exists, but it was subjected to complex chemical treatments. With the exception of that biosorbent, the others in this category have modest/medium lead retention properties, while the biosorbents tested in the present study have an unexpectedly high affinity for $\mathrm{Pb}^{2+}$ uptake.

\subsection{Real Mine Wastewater Characterization and Test Results}

For a better evaluation of adsorptive properties of grape marc wastes, a real aqueous matrix was tested: mine drainage water from Rosia Montana. Lead-bearing waters usually contain several other ions that may influence the $\mathrm{Pb}$ uptake process. The purpose of this test was to verify the level to which $\mathrm{ME}$ and SbE previously tested with synthetic monocontaminant solution, maintain their lead ion adsorption capacity in the presence of other metals. The characterization of real effluent is presented in Table 4.

As the analysis of the mine effluent showed a very low concentration of lead, it was enriched in this contaminant, by adding $\mathrm{Pb}\left(\mathrm{NO}_{3}\right)_{2}$ salt up to a concentration of $7.5 \mathrm{mg} / \mathrm{L}$ (value identical to the lowest concentration used in equilibrium isotherms assays). This lead concentration was considered more eloquent to prove the $\mathrm{Pb}^{2+}$ removal potential of grape marc biorefined waste in the presence of a complex matrix. Even in the presence of other heavy metals, the removal capacity is still very high, decreasing only from $86 \%$ to $75 \%$ for $\mathrm{ME}$ and to $72 \%$ for SbE (Figure 9), respectively.

This is a very good result, considering the complexity of the matrix and the fact that the competition between $\mathrm{Pb}$ and $\mathrm{Mn} / \mathrm{Fe} / \mathrm{Zn}$, which are present in important quantities, could obstruct the $\mathrm{Pb}$ removal. 
Table 4. Chemical characterization of Rosia Montana drainage water.

\begin{tabular}{cc}
\hline Parameter & Value \\
\hline $\mathrm{pH}$ & 2.78 \\
$\mathrm{CE}(\mathrm{mS} / \mathrm{cm})$ & 4.16 \\
$\mathrm{NO}_{3}^{-}(\mathrm{mg} / \mathrm{L})$ & 98.85 \\
$\mathrm{SO}_{4}{ }^{-}(\mathrm{mg} / \mathrm{L})$ & 984 \\
$\mathrm{Zn}(\mathrm{mg} / \mathrm{L})$ & 22.5 \\
$\mathrm{Cu}(\mathrm{mg} / \mathrm{L})$ & 0.92 \\
$\mathrm{Fe}(\mathrm{mg} / \mathrm{L})$ & 116.2 \\
$\mathrm{Mn}(\mathrm{mg} / \mathrm{L})$ & 604.6 \\
$\mathrm{Ni}(\mu \mathrm{Lg})$ & 0.59 \\
$\mathrm{~Pb}(\mathrm{mg} / \mathrm{L})$ & 0.02 \\
$\mathrm{Cd}(\mathrm{mg} / \mathrm{L})$ & 0.04 \\
$\mathrm{Cr}(\mathrm{mg} / \mathrm{L})$ & 0.02 \\
$\mathrm{Co}(\mathrm{mg} / \mathrm{L})$ & 0.09 \\
\hline
\end{tabular}

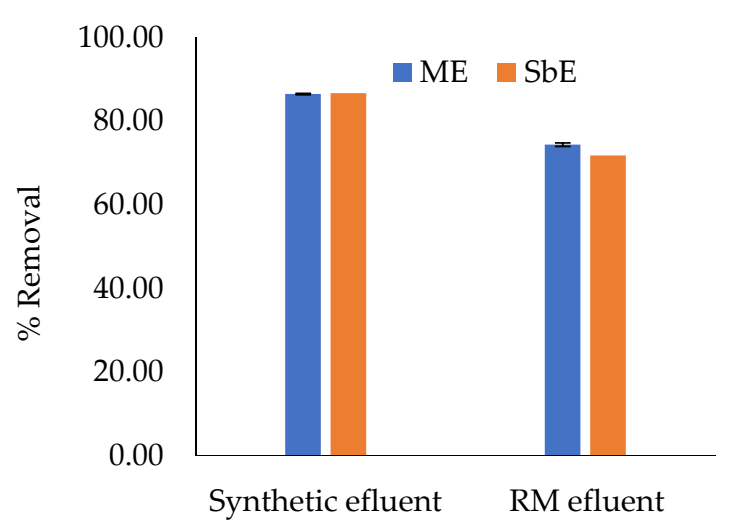

Figure 9. Removal efficiency of $\mathrm{Pb}^{2+}$ by $\mathrm{ME}$ and $\mathrm{SbE}$ from synthetic and real mining enriched (RM) effluent, initial $7.5 \mathrm{mg} / \mathrm{L} \mathrm{Pb}^{2+}$ solution, $0.5 \mathrm{~g} / \mathrm{L}$ adsorbent, $22{ }^{\circ} \mathrm{C}$.

\section{Conclusions}

Grape marc biorefined waste has proven to be a very good biosorbent for $\mathrm{Pb}^{2+}$ removal. The biosorption is a fast process that is strongly affected by $\mathrm{pH}$. Maximum adsorption capacities, predicted by the Langmuir model for $\mathrm{Pb}^{2+}$ were $40.14 \mathrm{mg} / \mathrm{g}$ for ME and 63.76 for $\mathrm{SbE}$, respectively ( $\mathrm{pH} 5.5,22^{\circ} \mathrm{C}$ ). Adsorption is an environmentally friendly and effective way of removing harmful pollutants from wastewaters. Further studies are recommended to test the effectiveness of the removal of other heavy metals. Additionally, the very good results obtained in this work allows us to consider this study as a starting point for future tests to improve the adsorptive properties of grape marc by applying thermal or other ecologically attractive and economically sustainable pre-treatments.

Author Contributions: Conceptualization, G.U. and A.P.; methodology, G.U., A.P. and I.G.C.; software, G.U., I.G.C., R.S. and A.G.-M.; formal analysis, G.U. and A.G.-M.; investigation, G.U., A.P., I.G.C. and A.G.-M.; resources, A.P. and R.S.; data curation, G.U.; writing-original draft preparation, G.U.; writing-review and editing, A.P.; supervision, A.P. and R.S.; project administration, A.P. and R.S.; funding acquisition, R.S. and A.P. All authors have read and agreed to the published version of the manuscript.

Funding: This work was funded by the Project 2SOFT/1.2/83 "Intelligent valorization of agro-food industrial wastes", funded by the European Union, within the program "Cross border cooperation Romania-Republic of Moldova 2014-2020". The funder had no role in the design of the study; in the collection, analysis, or interpretation of data; in the writing of the manuscript; or in the decision to publish the results.

Data Availability Statement: Not applicable. 


\begin{abstract}
Acknowledgments: The authors would like to thank the Project AUF-ECO_RI_SRI_2021_20_USAMVIIBI_ZERODECHET “Horticultural wastes in the benefit of health and environment, a new approach to the ZEROWASTE principle"; the Research and Development Station for Viticulture and Winemaking, Iasi, Romania; Filimon Vasile Razvan; and Baetu Marius Mihai.
\end{abstract}

Conflicts of Interest: The authors declare no conflict of interest.

\title{
References
}

1. Despoudi, S.; Bucatariu, C.; Otles, S.; Kartal, C. Food waste management, valorization, and sustainability in the food industry. In Food Waste Recovery, 2nd ed.; Galanakis, C., Ed.; Academic Press, Elsevier: London, UK, 2021; pp. 3-19.

2. Spigno, G.; Marinoni, L.; Garrido, G.D. State of the art in grape processing by-products. In Handbook of Grape Processing By-Products; Galanakis, C., Ed.; Academic Press, Elsevier: London, UK, 2017; pp. 1-27.

3. Baenas, N.; Abellán, Á.; Rivera, S.; Moreno, D.A.; García-Viguera, C.; Domínguez-Perles, R. Foods and supplements. In Polyphenols: Properties, Recovery, and Applications; Galanakis, C., Ed.; Woodhead Publishing, Elsevier: Duxford, UK, 2018; pp. 327-362.

4. Sagar, N.A.; Pareek, S.; Sharma, S.; Yahia, E.M.; Lobo, M.G. Fruit and vegetable waste: Bioactive compounds, their extraction, and possible utilization. Compr. Rev. Food Sci. Food Saf. 2018, 17, 512-531. [CrossRef]

5. Baiano, A. Recovery of biomolecules from food wastes-A review. Molecules 2014, 19, 14821-14842. [CrossRef] [PubMed]

6. Patras, A. Stability and colour evaluation of red cabbage waste hydroethanolic extract in presence of different food additives or ingredients. Food Chem. 2019, 275, 539-548. [CrossRef] [PubMed]

7. Rambabu, K.; Bharath, G.; Banat, F.; Show, P.L. Biosorption performance of date palm empty fruit bunch wastes for toxic hexavalent chromium removal. Environ. Res. 2020, 187, 109694. [CrossRef] [PubMed]

8. Rahim, A.R.A.; Mohsin, H.M.; Thanabalan, M.; Rabat, N.E.; Saman, N.; Mat, H.; Johari, K. Effective carbonaceous desiccated coconut waste adsorbent for application of heavy metal uptakes by adsorption: Equilibrium, kinetic and thermodynamics analysis. Biomass Bioenergy 2020, 142, 105805. [CrossRef]

9. Gupta, N.; Poddar, K.; Sarkar, D.; Kumari, N.; Padhan, B.; Sarkar, A. Fruit waste management by pigment production and utilization of residual as bio-adsorbent. J. Environ. Manag. 2019, 244, 138-143. [CrossRef]

10. Sandoval, V.J.L.; Castillo, D.I.M.; Petriciolet, A.B.; Villarreal, I.A.A.; Avila, H.E.R.; Ponce, H.A.G. Valorization of agri-food industry wastes to prepare adsorbents for heavy metal removal from water. J. Environ. Chem. Eng. 2020, 8, 104067. [CrossRef]

11. Heraldy, E.; Lestari, W.; Permatasari, D.; Arimurti, D.D. Biosorbent from tomato waste and apple juice residue for lead removal. J. Environ. Chem. Eng. 2018, 6, 1201-1208. [CrossRef]

12. Ameneiro, M.P.; Vecino, X.; Cruz, J.M.; Moldes, A.B. Physicochemical study of a bio-based adsorbent made from grape marc. Ecol. Eng. 2015, 84, 190-193. [CrossRef]

13. Harripersadth, C.; Musonge, P.; Isa, Y.M.; Morales, M.G.; Sayago, A. The application of eggshells and sugarcane bagasse as potential biomaterials in the removal of heavy metals from aqueous solutions. S. Afr. J. Chem. Eng. 2020, 34, 142-150. [CrossRef]

14. Yargıç, A.Ș.; Șahin, R.Z.Y.; Özbay, N.; Önal, E. Assessment of toxic copper (II) biosorption from aqueous solution by chemical-lytreated tomato waste. J. Clean. Prod. 2015, 88, 152-159. [CrossRef]

15. Gayathri, R.; Gopinath, K.P.; Kumar, P.S. Adsorptive separation of toxic metals from aquatic environment using agro waste biochar-Application in electroplating industrial wastewater. Chemosphere 2021, 262, 128031. [CrossRef] [PubMed]

16. Pap, S.; Knudsen, T.S.; Radonić, J.; Maletić, S.P.; Igic, S.M.; Sekulić, M.T. Utilization of fruit processing industry waste as green activated carbon for the treatment of heavy metals and chlorophenols contaminated water. J. Clean. Prod. 2017, 162, 958-972. [CrossRef]

17. Elias, M.A.; Hadibarata, T.; Sathishkumar, P. Modified oil palm industry solid waste as a potential adsorbent for lead removal. JECE 2021, 3, 1-7. [CrossRef]

18. Agarwal, A.; Upadhyay, U.; Sreedhar, I.; Singh, S.A.; Patel, C.M. A review on valorization of biomass in heavy metal removal from wastewater. J. Water Process. Eng. 2020, 38, 101602. [CrossRef]

19. Dermentzis, K.; Valsamidou, E.; Marmanis, D. Simultaneous removal of acidity and lead from acid lead battery wastewater by aluminum and iron electrocoagulation. J. Eng. Sci. Technol. 2012, 5, 1-5. [CrossRef]

20. Garrido, T.; Nikolaidis, M.G.; Leceta, I.; Urdanpilleta, M.; Guerrero, P.; De la Caba, K.; Kilmartin, P.A. Optimizing the extraction process of natural antioxidants from chardonnay grape marc using microwave-assisted extraction. J. Waste Manag. 2019, 88, 110-1147. [CrossRef]

21. Anjos, O.; Santos, A.J.A.; Estevinho, L.M.; Caldeira, L. FTIR-ATR spectroscopy applied to quality control of grape-derived spirits. Food Chem. 2016, 205, 28-35. [CrossRef]

22. Pap, S.; Bezanovic, V.; Radonic, J.; Babic, A.; Saric, S.; Adamovic, D.; Sekulic, M.T. Synthesis of highly-efficient functionalized biochars from fruit industry waste biomass for the removal of chromium and lead. J. Mol. Liq. 2018, 268, 315-325. [CrossRef]

23. Casazza, A.A.; Aliakbarian, B.; Lagazzo, A.; Garbarino, G.; Carnasciali, M.M.; Perego, P.; Busca, G. Pyrolysis of grape marc before and after the recovery of polyphenol fraction. Fuel Process. Technol. 2016, 153, 121-128. [CrossRef]

24. Bhattachajee, C.; Dutta, S.; Saxena, V.K. A review on biosorptive removal of dyes and heavy metals from wastewater using watermelon rind as biosorbent. Adv. Environ. 2020, 2, 100007. [CrossRef] 
25. Bauzá, A.; Seth, S.K.; Frontera, A. Tetrel bonding interactions at work: Impact on tin and lead coordination compounds. Coord. Chem. Rev. 2019, 384, 107-125. [CrossRef]

26. Ahmad, A.; Khatoon, A.; Setapar, S.H.M.; Kumar, R.; Rafatullah, M. Chemically oxidized pineapple fruit peel for the biosorption of heavy metals from aqueous solutions. Desalination Water Treat. 2015, 57, 1005150. [CrossRef]

27. Ungureanu, G.; Volf, I.; Boaventura, R.A.R.; Santos, S.C.R.; Botelho, C.M.S. Biosorption of antimony oxyanions by brown seaweeds: Batch and column studies. J. Environ. Chem. Eng. 2017, 5, 3463-3471. [CrossRef]

28. Mansoorian, H.J.; Mahvi, A.H.; Jafari, A.J. Removal of lead and zinc from battery industry wastewater using electrocoagulation process: Influence of direct and alternating current by using iron and stainless-steel rod electrodes. Sep. Purif. Technol. 2014, 135, 165-175. [CrossRef]

29. Volf, I.; Rakoto, N.G.; Bulgariu, L. Valorization of Pistia stratiotes biomass as biosorbent for lead (II) ions removal from aqueous media. Sep. Sci. Technol. 2015, 50, 1577-1586. [CrossRef]

30. Filote, C.; Volf, I.; Santos, S.C.R.; Botelho, C.M.S. Bioasorptive removal of $\mathrm{Pb}^{2+}$ from aqueous solution by the biorefinery waste of Fucus spiralis. Sci. Total Environ. 2019, 648, 1201-1209. [CrossRef]

31. Ho, Y.S.; Wase, D.A.J.; Forster, C.F. Kinetic studies of competitive heavy metal adsorption by sphagnum moss peat. Environ. Technol. 1996, 17, 71-77. [CrossRef]

32. Abdelfattah, I.; Ismail, A.A.; Al Sayed, F.; Almedolab, A.; Aboelghait, K.M. Biosorption of heavy metals ions in real industrial wastewater using peanut husk as efficient and cost-effective adsorbent. Environ. Nanotechnol. Monit. Manag. 2016, 6, 176-183. [CrossRef]

33. Ben Amar, M.; Walha, K.; Salvado, V. Evaluation of olive stones for $\mathrm{Cd}(\mathrm{II}), \mathrm{Cu}(\mathrm{II}), \mathrm{Pb}^{2+}$ and $\mathrm{Cr}(\mathrm{VI})$ biosorption from aqueous solution: Equilibrium and kinetics. Int. J. Environ. Res. 2020, 14, 193-204. [CrossRef]

34. Wang, F.; Pan, Y.; Cai, P.; Guo, T.; Xiao, H. Single and binary adsorption of heavy metal ions from aqueous solutions using sugarcane cellulose-based adsorbent. Bioresour. Technol. 2017, 241, 482-490. [CrossRef] [PubMed]

35. Liu, J.; Hu, C.; Huang, Q. Adsorption of $\mathrm{Cu}^{2+}, \mathrm{Pb}^{2+}$, and $\mathrm{Cd}^{2+}$ onto oiltea shell from water. Bioresour. Technol. 2019, $271,487-491$. [CrossRef] [PubMed]

36. Mallampati, R.; Xuanjun, L.; Adin, A.; Valiyaveettil, S. Fruit peels as efficient renewable adsorbents for removal of dissolved heavy metals and dyes from water. ACS Sustain. Chem. Eng. 2015, 3, 1117-1124. [CrossRef]

37. Kamar, F.H.; Nechifor, A.C.; Nechifor, G.; Al-Musawi, T.J.; Mohammed, A.H. Aqueous phase biosorption of $\mathrm{Pb}^{2+}, \mathrm{Cu}(\mathrm{II})$, and Cd(II) onto cabbage leaves powder. Int. J. Chem. React. Eng. 2017, 15, 20150178. [CrossRef] 